\title{
Interfaces
}

INTERFACES Image Texte Language

$45 \mid 2021$

Jeux de formats (1)

\section{Edward Ardizzone's Multimedial Play with Format in his War Diaries}

Julie LeBlanc

\section{Q OpenEdition \\ 1 Journals}

\section{Electronic version}

URL: https://journals.openedition.org/interfaces/2358

DOI: 10.4000/interfaces.2358

ISSN: 2647-6754

Publisher:

Université de Bourgogne, Université de Paris, College of the Holy Cross

\section{Printed version}

Date of publication: 12 July 2021

ISSN: 1164-6225

\section{Electronic reference}

Julie LeBlanc, "Edward Ardizzone's Multimedial Play with Format in his War Diaries", Interfaces [Online], 45 | 2021, Online since 12 July 2021, connection on 18 September 2021. URL: http://

journals.openedition.org/interfaces/2358 ; DOI: https://doi.org/10.4000/interfaces.2358

This text was automatically generated on 18 September 2021.

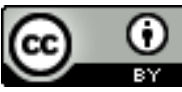

Les contenus de la revue Interfaces sont mis à disposition selon les termes de la Licence Creative Commons Attribution 4.0 International. 


\title{
Edward Ardizzone's Multimedial Play with Format in his War Diaries
}

\author{
Julie LeBlanc
}

To acquire a good visual memory and knowledge another practice is essential: the practice of really looking at things and trying to commit them to memory. In this context the keeping of an illustrated diary helps enormously. (Ardizzone, "The Born Illustrator" 38)

1 Edward Jeffrey Irving Ardizzone (CBE, RA, 1900-1979) was an internationally known English painter, printmaker, author, and illustrator of children's books. ${ }^{1}$ From 1940 to 1945 he was also a commissioned artist by the WAAC (War Art Advisory Committee) ${ }^{2}$ and executed world-renowned ink and watercolors. He painted army manoeuvres before the war in England, scenes of destruction during the Blitz in London and executed a series of shelter drawings and paintings. As a commissioned war artist, he travelled with the British Army, visiting Italy, France, Germany, Belgium, Denmark, Ireland, Scotland, Egypt and Algeria. He travelled to Italy with the $50^{\text {th }}$ Battalion during the invasion of Sicily in July 1943, which marks the beginning of his first diary. He concluded his travels in Germany with the $8^{\text {th }}$ Hussars in May 1945 describing and sketching images of the closing months of the war in his fourth and last diary. His travels throughout Europe and North Africa between 1943 and 1945 are documented in four illustrated diaries published in 1974 and entitled Diary of a War Artist. During his travels he kept diaries to document his impressions of war and sketched what he witnessed in these war-stricken countries. Some of his detailed descriptions of warscapes, images he sketched or painted, helped in the execution of larger ink washes and watercolors for the WAAC. His record of WWII is contained in some 275 drawings, ink and washes as well as numerous watercolors all in the collections of the Imperial War Museum in London. Other images, approximately 400, also produced during the war, are scattered in galleries, museums, and private collections in Britain. ${ }^{3}$ 
Figure 1. Cover of the manuscript version of Ardizzone's $3^{\text {rd }}$ diary dated May 1943-January 1944.

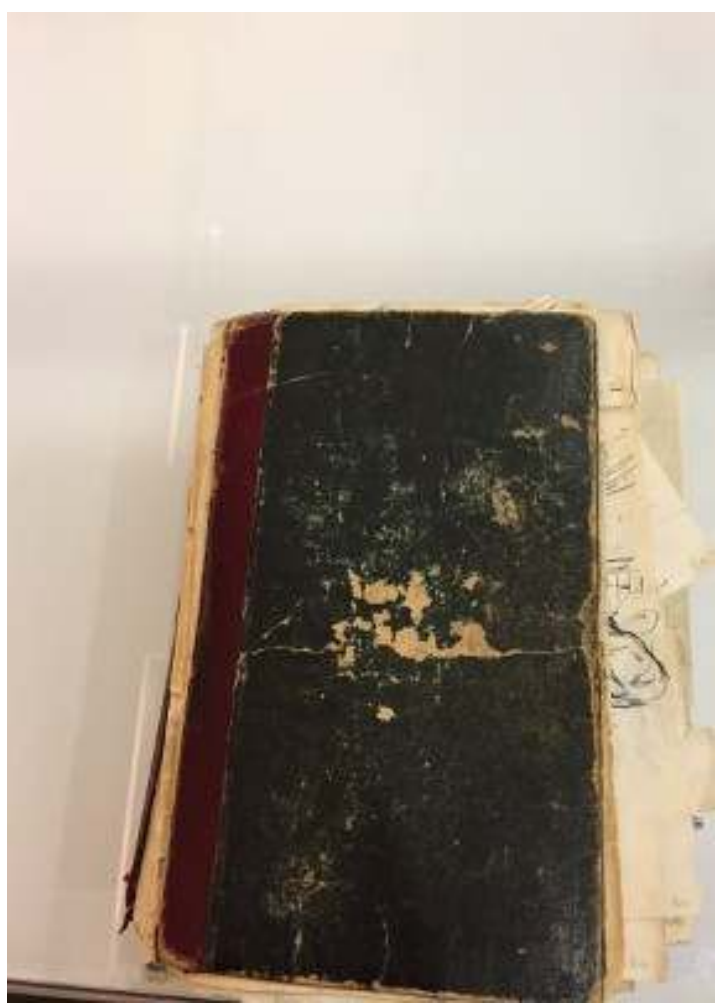

Author's photograph with the permission of the Imperial War Museum. The black hard-covered diary is bulging with extra pieces of paper where dozens of unpublished sketches are embedded between the pages of his hand-written illustrated diary.

(c) The Ardizzone Trust.

2 Ardizzone was an accomplished and prolific artist but in view of the thematic framework of this publication, I have chosen to analyse the format of some of his drawings, as well as some of the ink and washes introduced within the manuscript pages of his diaries and Diary of a War Artist. I am more specifically interested in the ink sketches produced in the manuscripts of his four diaries (between 1943 and 1945), the black and white sketches published decades later in Diaries of a War Artist, the numerous unpublished images embedded between the manuscript pages of his illustrated diaries held at the Imperial War Museum in London and some of his artworks inspired from many of the unpublished and published images of war (Fig. 1). Ardizzone's diaries represent a rich literary and pictorial corpus to study the aesthetic and transformative elements of format. Ardizzone's play with format is multidimensional and complex as he uses various media (pencil, pen, watercolor, ink and wash) and different supports: pages of his bound diaries, sheets of paper, graph paper and watercolor paper. The ever-changing format of his sketches (their various dimensions, horizontal and vertical placements within the diary entry) always interrupts Ardizzone's narrative. Finally, the discrepancies I have observed between the manuscript versions of his diaries and their published edition (Diary of a War Artist) add another layer of complexity to my study of how format influenced Ardizzone's creative output but also imposed physical restrictions on his artistic endeavours.

3 Using Thomas Tanselle's definition of format, which references various fundamental elements, one quickly recognizes that we must go beyond the physical and design characteristics of Ardizzone's diaries in order to grasp the evolution of the word/image 
relationship which is displayed within the manuscripts, the published edition of his diary and the detailed paintings which his original sketches gave rise to. In editorial circles and fields of inquiry related to book history, the concept of format refers to different "kinds of materials" included in a book, its physical form, design, "layout, topography and overall dimension", the spatial arrangement of the words and the images, the elements which connect the "physical structure of a book with scribal procedures", the "shape and size of a book", as in its "forma magna" (68). Due to the complexity of Ardizzone's diaries, it is obvious that we must go beyond a restrictive conception of format in order to embrace the autobiographical, artistic, political, symbolic, transformative nature of his particular use of format (in his personal and pictorial testimonial of WWII). Tanselle's limited definition of format is useful since it provides a metalanguage to speak of the physical, material and typographical characteristics of Ardizzone's diary. Yet its complexity can be better addressed by David Zerbib's suggestions that format be treated as an "opérateur clé" (key device) and "construction médiatrice" (medial construct):

The notion of format in fact refers to a poorly identified plan, because it is too often relegated [...], too often described as a simple technical variable [...]. It is however legitimate to consider it as a key operator of material and symbolic practices. We propose that it be treated as a mediating construction that controls modes of inscription, encoding, translation, implementation, exposure, filtering and use of forms and information. ${ }^{4}$

\section{A general introduction to Ardizzone's diaries: The manuscripts and published edition}

Figure 2. An example of the unpublished sketches embedded between the pages of his diaries.

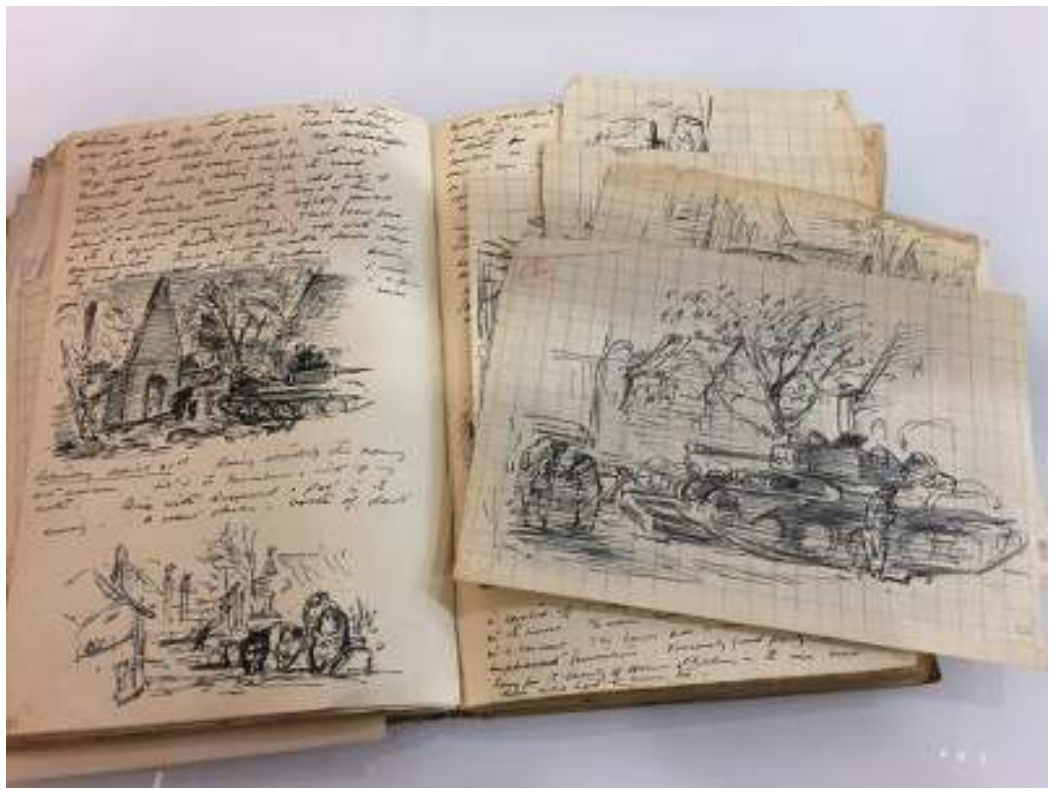

Author's photograph with the permission of the Imperial War Museum.

(c) The Ardizzone Trust.

4 As these examples indicate, Ardizzone's diaries distinguish themselves by their textual and pictorial hybridity: they are saturated with figures of ekphrasis, vivid descriptions 
of what he witnessed, and emotional reactions to the human and material casualties of war. They are also punctuated with realistic and figurative sketches of landscapes, military paraphernalia, portraits of soldiers and civilians encountered during his travels across Europe and North Africa between 1943 and 1945. The complexity of the word and image relationship is further enhanced when one compares the manuscript versions of these illustrated autobiographical narratives and their published edition (Diary of a War Artist). What I have observed is that, notwithstanding a few exceptions, the published edition of his four diaries faithfully represents Ardizzone's original narrative, descriptions and impressions as they were initially written and illustrated during the war. However, the illustrated aspect of Ardizzone's published diaries presents us with certain challenges. While many of the images reproduced in Diary of a War Artist respect the original format used in the manuscript pages, there are however important discrepancies between the hand-written, illustrated pages of his diaries and the published edition (Fig. 3).

Figure 3. A Fragment from Diary of a War Artist dated Novembre 1944.

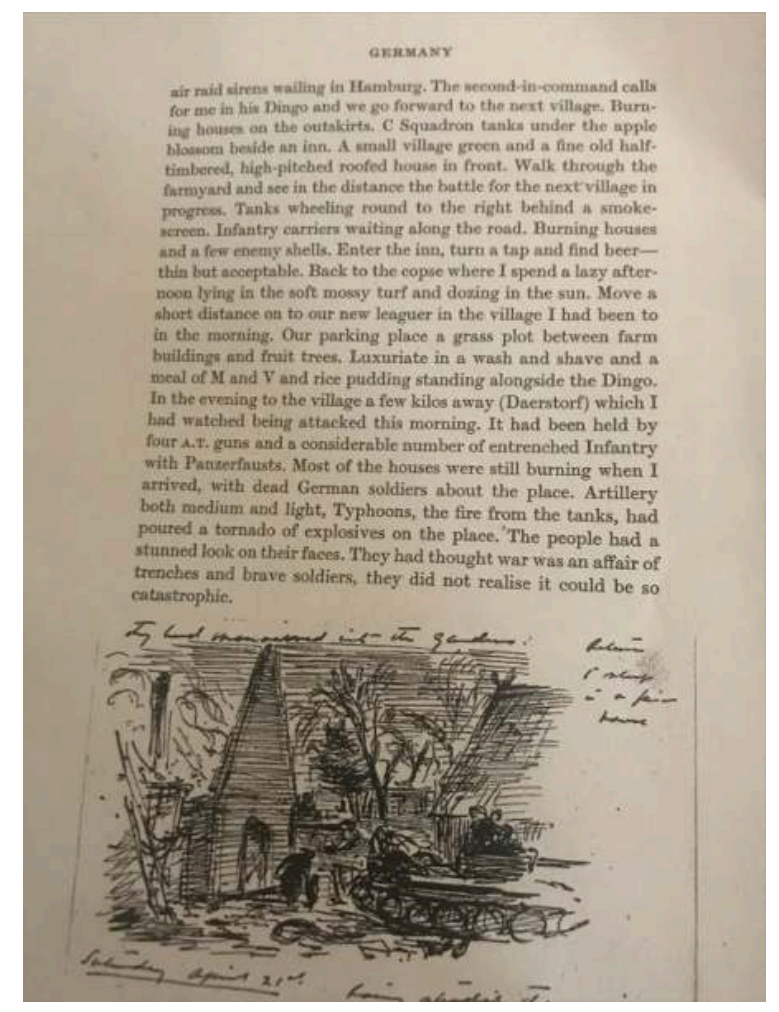

When one compares the placement of the sketched image in Diary of a War Artist to the original manuscript of the same diary entry (Fig. 4), obvious discrepancies between the published edition and hand-written manuscripts are easily recognizable.

(c) The Ardizzone Trust.

5 The sketches are often displaced and do not appear as they did within the manuscript pages of the diary. This ultimately compromises the word and image relationship that Ardizzone had originally intended to accentuate in his diaries. At times, the descriptions of what he has witnessed precede the sketches, in other instances the sketches precede the descriptions and, in some excerpts, instances of ekphrasis prevail in the entries, providing vivid descriptions of the images. It is obvious that computer technology, word processing and scanning techniques were not developed in the 1970s 
when Diary of a War Artist was published. These technologies would have allowed for a more faithful representation of the word/image relationship which the manuscripts so beautifully display. To compensate for the discrepancies between the manuscript version of his diary and the final published edition, Ardizzone and his editors included black and white photographs of some of the textual and visual sketches: this allows the reader to have a sense of the original format of the diaries and the manner in which the written words and beautifully sketched images interact with one another. Finally, the most important discrepancy between the hand-written and published edition of Ardizzone's diary comes from the fact that the numerous sketches, as well as the ink and wash images executed outside the bound pages of the diaries, and loosely embedded between the pages of the diaries, were not reproduced in the published edition at the rare exception of a few images.

6 Format is obviously pertinent as it pertains to the material disposition of the handwritten words and of the sketched images which enliven almost every single page of his diaries: like the ever-changing format of his drawings, which fluctuates from landscape (horizontal) to portrait (vertical) formats, Ardizzone's hand-writing, which is obviously syntagmatic, appears at times as being paradigmatically laid out on numerous pages of his diary. The writing is either interrupted by the execution of an image or the image finds itself constrained by Ardizzone's descriptions. We have also observed that in certain cases Ardizzone's narrative is not accompanied by illustrations. The absence of image may be due to the fact that the entry's subject matter is not a suitable candidate for an illustration or to specific circumstances (weather, bombings, etc.). In certain contexts, Ardizzone admits that he cannot draw the atrocities of what he has witnessed and therefore limits himself to the written word to bear witness to the material and human casualties of war. In these instances, the horrific scenes are rendered by detailed descriptive passages void of any supporting illustrations. Since the great majority of the images (pencil, ink, and ink/wash) executed on loose pieces of paper and inserted between bound pages of his four notebooks remain almost entirely unpublished, their relationship to the larger ink and wash paintings and watercolors executed for the WAAC has also remained unscrutinised.

\section{Support and format}

7 It is generally recognized that paintings and drawings are designed "in concert with the support on which they are created" (Mize) and, in Ardizzone's case, we are dealing with the small pages of his bound notebooks. When the spatial constraints of his diaries are too limiting in terms of what he wants to draw, he turns to loose sheets of paper approximately the size of his diaries so that they can easily be embedded between the pages for safe-keeping. In exceptional cases, if the initial sketch introduced in the diary gives rise to a colorful ink and wash, then the support changes to a more substantial permeable thick watercolor paper. As Dianne Mize and other artists remind us, format is always an important composing tool and plays different roles in the "placement of the subject" represented and in its potential for communicating the "spirit" of a drawing or painting (Mize). Format is also a tool that can be used by artists to enhance the thematic focus of the artwork or to render their personal or social understanding of the individuals, landscapes, still-life featured in the images. Ardizzone's support is paper, the medium is black ink and the dimensions of his hard cover diaries are 
rectangular: they are $175 \mathrm{~mm}$ high and $220 \mathrm{~mm}$ wide. Contrary to what we may find with other artists' chosen supports, the subjects drawn within his diaries diverge greatly from one page to another as if the support did not dictate how the sketched subjects were composed: they are placed horizontally and vertically on the pages of the diaries and their relationship to the written words vary greatly from one page to the next. At times, they complement each other, and in other instances, the descriptions that are provided, such as references to the human casualties of war, are not illustrated. This particular photograph taken from the preliminary pages of Ardizzone's first diary exhibits how format is complicated by the word/image interactions exhibited, and the support and medium used (Fig. 4). The sketches punctuate the pages of his diary, interrupt the narrative and their relationship to the written words fluctuates. Some serve to actually illustrate the descriptive passages, while others have a distant relationship with the narrative.

Figure 4. The seven images sketched within the two small pages of Ardizzone's diary are dated November 1941.

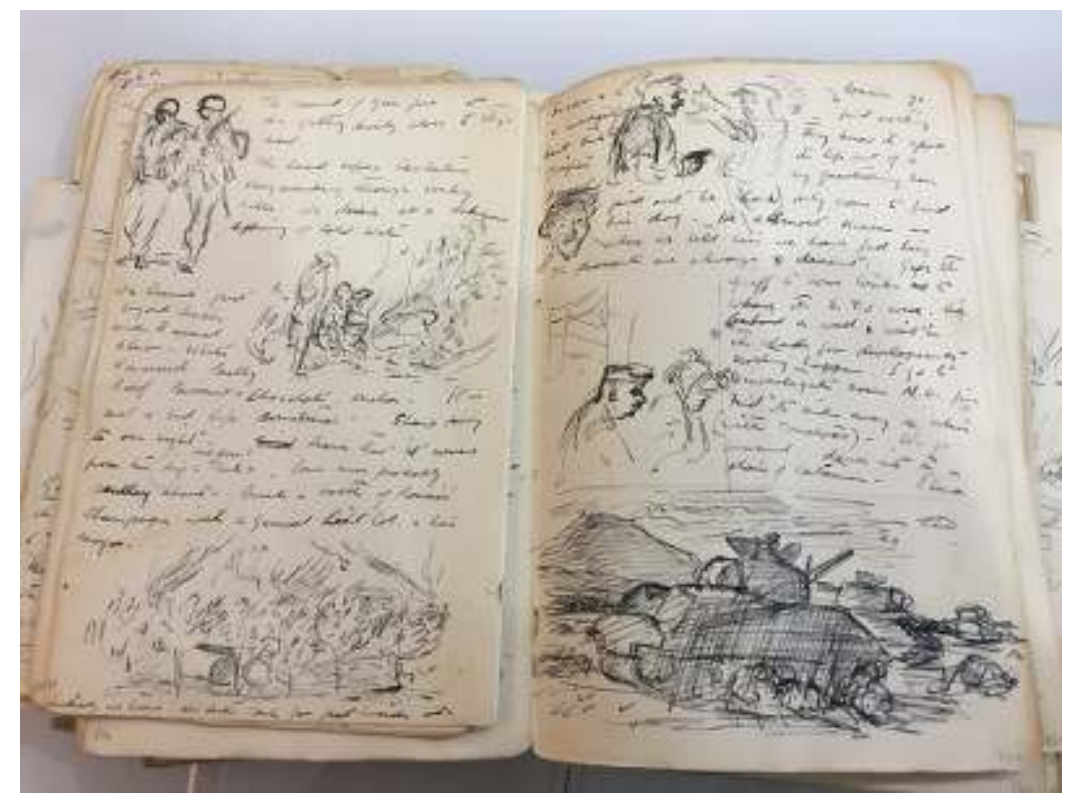

They are great examples of how images and words appear to be competing with one another due to the restrictive space that the diary offers. Imperial War Museum.

(c) The Ardizzone Trust.

These images of war paraphernalia are punctuated with Ardizzone's narrative, where he describes the war-stricken landscape of Sicily (Etna, Carlentini, Lentini, Catania; "town's children begging for food"), the casualties of war ("Dead bodies burnt vehicles and prisoners on the road") and the presence of British military in jeeps, tanks and on foot as they forge through much of Sicily in mid July 1943: "The sound of gunfire, we are getting fairly close to things now [...] Etna smoking high in front of us. Our tanks dotted about in a cornfield. Machine-gun and air bursts. Catania in the distance beyond the plain" (Diary of a War Artist 10). In many instances, Ardizzone's descriptive passages contextualize the images he has drawn (" $15^{\text {th }}$ of July Thursday [1943]") offering details about the Sicilian towns he travelled through with the British army and referencing the sounds of gun fire and "dead bodies." Although human casualties of war are not sketched by Ardizzone in his four diaries - if we except one single impressionistic 
image - his diary entries often present detailed descriptions of the "smell of dead bodies" with references to the fact that the atrocities that he has witnessed cannot be drawn:5 " $17^{\text {th }}$ of July 1945 , must try and make some drawings of the horrors but don't want to; such a terrible mess that I find it difficult to draw" (11). In these excerpts, when no complementary image is sketched, Ardizzone is extremely explicit in referencing his visceral reactions to the terrible odors and horrific sounds of warfare: " $21^{\text {st }}$ of July 1943 Sicily, [...] dead bodies, burnt out vehicles, prisoners, sound of gunfire, the smell of dead bodies, a smell that hangs on everywhere, visible shell bursts, bodies disembowelled, blackened legs and arms gone, the smell of roasting bodies from two tanks [...]" (20). As he cannot bring himself to sketch what he witnesses, in certain instances, Ardizzone simply sketches portraits of soldiers, civilians and war paraphernalia, omitting from his diary the illustrations of the most gruesome aspects of war. In this particular example, taken from the beginning of his first diary, the words and images are horizontally and vertically laid out. The sketches and words compressed into the pages of his small notebooks appear to be competing with one another as space is scarce (in these bound pages of his diaries). Format is a multifaceted consideration which pertains to the constraints of the literary genre adopted (a chronologically narrated diary), the support used (small bound notebooks and loose pages of paper) as well as the media used to transform small ink sketches into larger watercolors.

\section{The manuscripts of Ardizzone's illustrated diaries: generic hybridity, genetic significance and formal challenges}

Michel Collot suggests that most writers' notebooks ("carnets de travail") present practical advantages as they are compact and allow writers and artists to document, in a spontaneous manner, what they see "sur le vif" (on the spot) or what inspires them (178). As Pierre-Marc de Biasi proposes, notebooks are often either dedicated to documenting the writer's travels or his creative output. However, as Ardizzone's four diaries clearly evidence, "the difference between notebooks acting as travel narratives and those focussed on the writers/artists work in progress, is at times very fluid when their objectives have a documentary purpose".${ }^{6}$ As we have noticed, his diaries are filled with references to various countries he visited with the British army and they display characteristics commonly found in travel narratives ("carnets de voyage"). The sketches which are scattered amongst these descriptive passages exhibit characteristics commonly found in artists' sketchbooks ("carnets de travail") as their purpose is to commit to memory what he has witnessed with the objective of executing more detailed watercolors starting from the preliminary sketches he has drawn. At other times, his illustrated travel narratives are interspersed with his visceral reactions to what he witnesses and, in these instances, we have the impression of reading an intimate diary. As Ardizzone suggests in the introduction to Diary of a War Artist these two functions were fundamental to the artistic production commissioned by the WAAC: "though this diary was in every way a private and personal one, I found that it also became a valuable addition to my method of making hieroglyphic notes on the spot. It helped me enormously in the work of producing paintings for the War office. It helped 
me to clarify what I wanted to say in the visual terms of a picture, or rather to make a pictorial comment" (viii).

$20^{\text {th }}$ of April Thursday [1944]

[...]. We pass through three much battered, grey hill villages at one of which (San Clemente) I make a drawing. Then down between narrow stony hills to a bare green valley and see the astonishing sight of the ruined village of San Pietro [...] a village almost completely destroyed. It had the gruesome effect of a surrealist nightmare. We approached it though an olive grove of blackened and shell-torn trees. On through blasted olive groves [...]. Cassino so flattened it looks like a fall of rock and rubble on the hillside. [...], Our guns firing and dots of air bust over the enemy positions. [...]. Things to remember - women washing clothes at a stream beside a heavy gun. A column of Goums on horseback and clothed in their striped blankets [...]. Bivouacs on ledges beside a ravine. (118-19).

Ardizzone's diaries display many of the features that Collot and de Biasi describe in their study of writers'/artists' notebooks: the fluctuation between literary genres ("récit de voyage"/travel narrative, "document génétique"/genetic functions, "journal personnel"/personal diary) that are so characteristic of many artists' "carnets de travail" (notebooks).This excerpt presents many of the features that are commonly found in Ardizzone's diaries and his detailed descriptions of war-scapes, ("a village almost completely destroyed, blackened and shell-torn trees, ruined towns, guns firing"), his emotional reaction to what he witnesses ("the gruesome effect of a surrealist nightmare"), and the genetic function he attributed to his diary ("things to remember - women at a stream beside a heavy gun," etc.). These excerpts, like many diary entries, are focused on the destruction caused by war, the military personnel he encounters, war paraphernalia, landscapes/war-scapes and civilians he has met in the various war-stricken countries he travels through with the British army. From a vivid detailed description of the destruction of warfare by enemy forces ("Cassino so flattened, looks like a fall of rocks and rubble on the hill side"), Ardizzone moves on a different perspective on war in his November 1944 diary entry: the British and their allies prepare with substantial ammunition to fight off the Germans with a "cortège" of vehicles including a tank, an Ark, Dingo, and Churchill:

$21^{\text {st }}$ November Tuesday [Italy 1944]. In the morning wander round the locality. Find tanks, Arks, machine-gun and mortar sections tucked away in farmyards or deployed under the trees [...]. (152)

23 November Thursday. Finally, we set off at dawn. I had great difficulty in getting into the tank, had to take most of my clothes off. A Churchill with no turret and a great bundle of sticks in front led the way, then the Ark, a Dingo or two, a turretless Honey and ourselves ended the cortège. By the stream could just see the Ark wallowing down through the deep mud to settle itself in position. (153-54) 
Figure 5. This image drawn on the right-hand side of the diary entry was the preliminary sketch used to execute his painting (Fig. 6). Imperial War Museum.

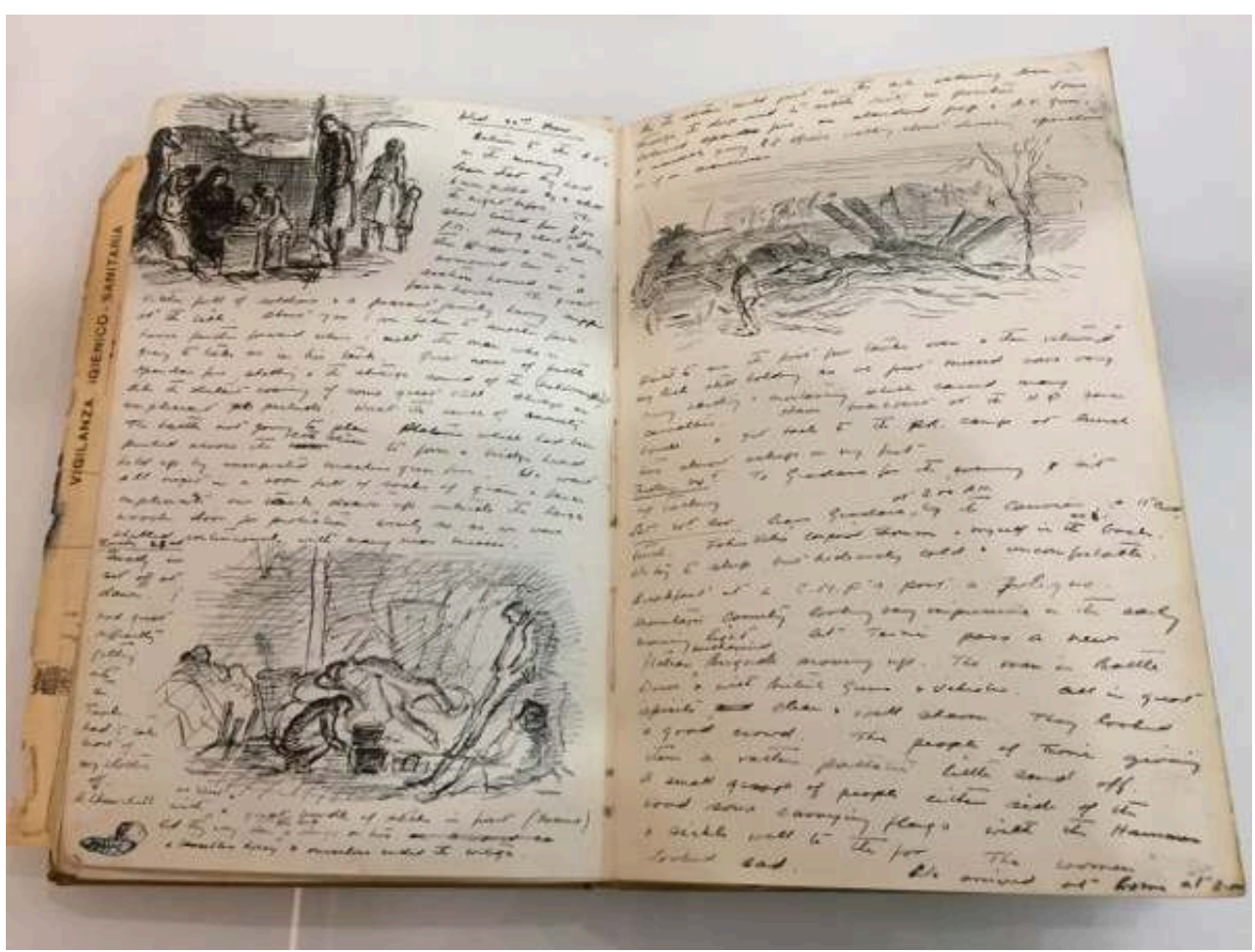

(c) The Ardizzone Trust.

Figure 6. Ink and wash (Italy, November 1944) inspired by the previous sketch (Fig. 5).

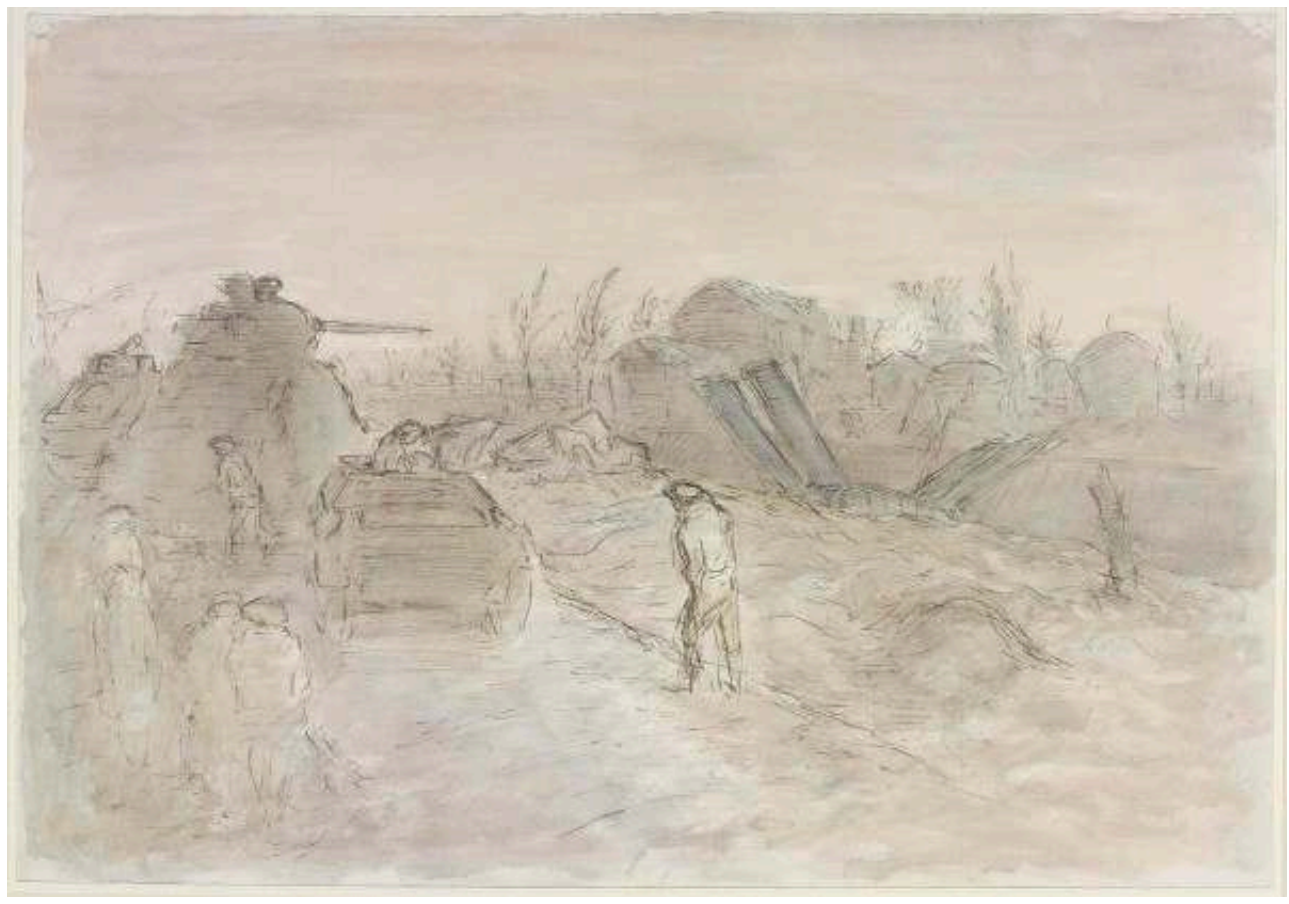

It is a fine example of how many of his sketched image introduced within the manuscript pages of his four diaries evolved into final ink and wash paintings for the War Art Advisory Committee and eventually exhibited. Imperial War Museum IMW-ART-LD 004783.

(c) The Ardizzone Trust. 
11 The subsequent diary entries are illustrated with sketches which faithfully represent the war paraphernalia and the military power of warfare so vividly described in Ardizzone's notebook. References to a tank, Churchill and Dingo lined up in the form of a "cortège" with the Ark in position settled into its own depression into deep mud and ready to attack the Germans. ${ }^{7}$ The word and image relationship highlighted in the manuscript pages of this diary entry, the manner in which the work was reproduced in the published edition, and the watercolor and ink images which the initial sketches inspired suggest that supports, dimensions and media are meaningful. The formatting of the word/image relationship is affected by these parameters. The publication of the image does not respect its original placement within the manuscript page of the handwritten diary. In Diary of a War artist, the format adopted places the image between two fragments of the diary entry dated " $23^{\text {rd }}$ November Thursday [1944]": the sentence in which it is embedded is fragmented by the reproduction of the sketch prominently displaying the Ark "wallowing through the deep mud." The ink and watercolor entitled "An Ark Bridge Tank Moving into Position at Dawn" is an impressionistic, sombertinted rendition of the angular ink drawing executed in his diary: the various shades of beige are reminiscent of the dominant presence of mud so often described within his war-scapes.

\section{The formal constraints of the bound pages of the diaries}

Turning to small notebooks to describe and sketch what he had witnessed was extremely practical even though this format presented obvious spatial constraints. The diary entries which cover two years of travel with the British Army as an artist for the WAAC are carefully dated. However, as Ardizzone could not describe and sketch everything he witnessed between 1943 and 1945 as he travelled through Europe and North Africa, he obviously made choices as to what he included in the entries of his diaries. As Suzanne L. Bunkers and Cynthia A. Huff suggest, the “diary's flexibility and adaptability enhance its uses in our lives [...], its form simultaneously elastic and tight [...] its content wide ranging yet patterned, and what is excluded is as important as what is included" (1). The autobiographical genre, the structured, dated diary entries, and more importantly, the dimensions of the pages $(220 \mathrm{~mm} \times 175 \mathrm{~mm}$ ) of his bound notebooks also shaped Ardizzone's practice. The limited space that the pages of his diaries allotted him led to the execution of dozens of sketches/ink and watercolors on single pieces of paper which were then placed between the pages of his bound diaries. The numerous, predominantly unpublished sketches found embedded between the manuscript pages of his four diaries conserved at the Imperial War Museum were never published in Diary of a War Artist in 1970 at the exception of one colorful ink and wash that I reproduce in this article (Fig. 9, image place on the right-hand side). 
Figure 7. This detailed sketch reproduced in Diary of a War artist (Germany, May 1945) was transformed into a colorful ink and wash (Fig. 8). Imperial War Museum.

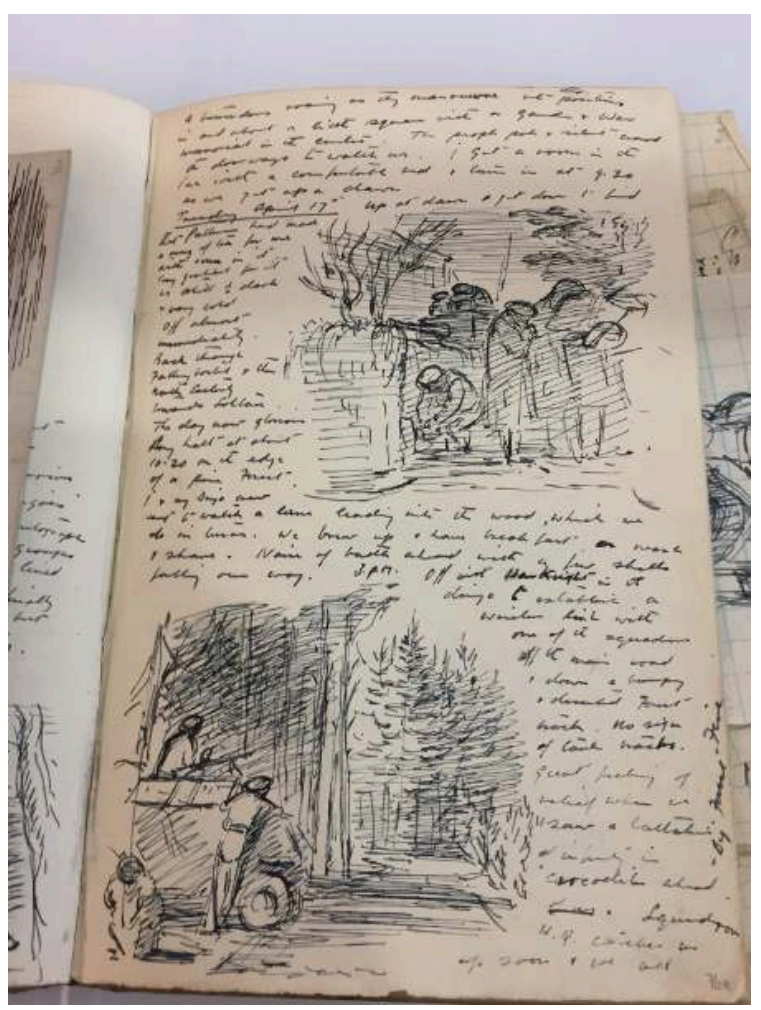

(c) The Ardizzone Trust. 
Figure 8. Ink and wash painting inspired by the previous sketch (Fig. 7) found with the manuscripts of his diary.

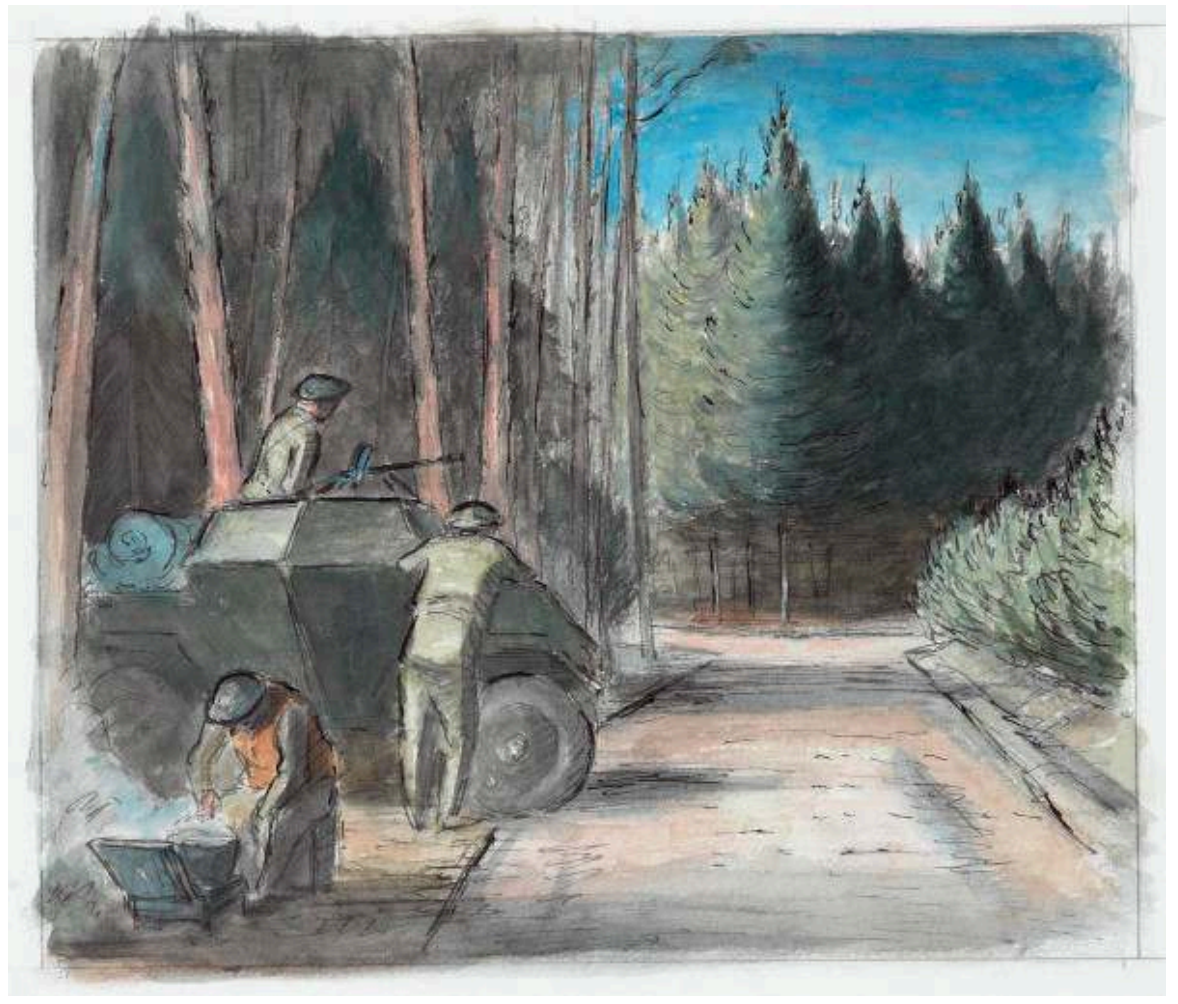

The IWM website describes this colorful image in this manner: "Germany, May 1945. With the $8^{\text {th }}$ Hussars in Germany: the crew of a scout-car keeping watch on a woodland road". URL: https:// www.iwm.org.uk/collections/item/object/713 Imperial War Museum IMW-ART-LD 005437.

(c) The Ardizzone Trust.

Whether they are included with the pages of his diaries (Fig. 7) or are the subject of larger ink and washes inspired from the initial sketches (Fig. 8), Ardizzone's compositions often use the same classical rules. Alan Powers describes his compositional style in this manner: the "diagonals intersecting near the center, whether or not reinforced by perspective lines [...]" reference Ardizzone's particular perspective, "imagining himself either in the stalls or the circle of a theatre" (56). Almost all of his sketches are "war-scapes," they are largely documentary in nature and destined to show the eventual "home audience what things were like at a time when color photography was seldom used and painting still had the edge for the portrayal of atmosphere" (45). The ink and washes which resulted from the initial sketches display similar drawing techniques: his "quick outline drawings in pencil and pen, are often executed to capture figures of groupings with varying levels of background detail" (71). In a few of the diary entries, the evolution of these pencil/ink figures (landscapes/ war-scapes or individual/group portraits) is visually perceivable as Ardizzone briefly outlines what he has observed, then provides a more detailed sketch of the outlined figures and finally frees himself from the physical constraints of the notebook format to execute a more vivid adaptation of the sketched image which necessitates a change of support (watercolor paper) and medium (ink and watercolor). The expanded versions of various preliminary sketches and detailed colorful ink and washes (displaying gridding lines), often serve to execute a more detailed drawing or ink and wash. The grid lines are used in these rare colorful ink and wash images found with the 
manuscripts of his diaries, affecting the composition and scale of the larger images he would eventually paint. The following excerpts instantiate the correlation between the evolution of images within the manuscript pages of his diaries, their reproduction within Diary of a War Artist and the paintings that the original sketches inspired.

Figure 9. This particular manuscript page taken from Ardizzone's diary is unusual as the two images sketched on the left-hand side were never published in Diary of a War Artist. Ardizzone and/ or his editor chose to reproduce the colorful graded ink and wash painting that I found inserted between the pages of his diary. It is executed on thicker watercolor paper. These three images offer insightful information in respect to the evolution of his final famous painting: The Wehrmacht (Fig. 10). Imperial War Museum.

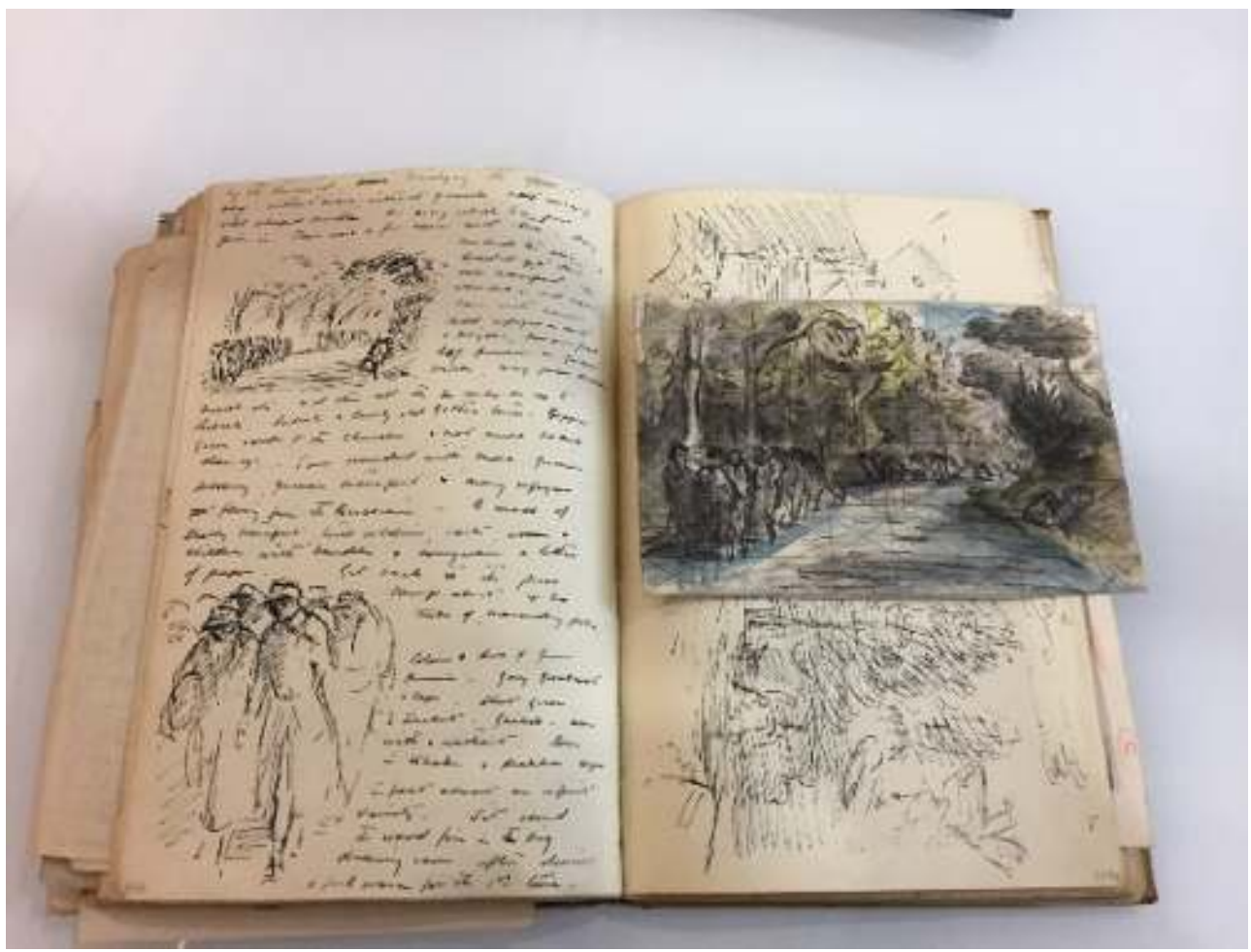

(c) The Ardizzone Trust. 
Figure 10. Final ink and wash painting The Wehrmacht which was inspired by the three previous images that I found with the manuscript pages of Ardizzone's diary. Imperial War Museum IMWART-LD 005436.

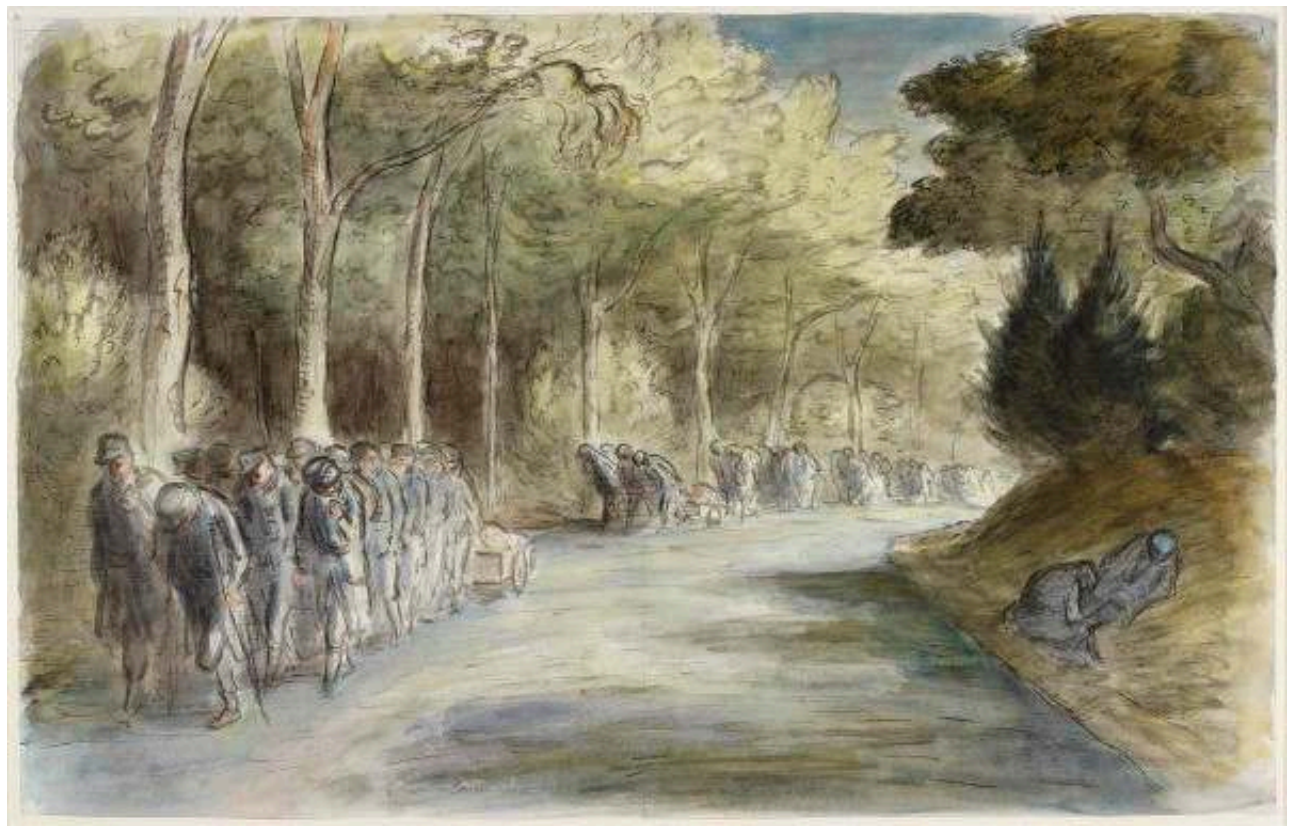

(c) The Ardizzone Trust. witnessed. It would eventually culminate in his scaled up ink and watercolor on paper measuring $489 \mathrm{~mm}$ in height and $713 \mathrm{~mm}$ in width. It is referred to by the IWM as the The Wehrmacht, May 1945 and perceived as one of Ardizzone's most famous war paintings (Fig. 9 and 10). ${ }^{8} \mathrm{He}$ is in Lunenburg on $3^{\text {rd }}$ May 1945 and these images are some of the last war-scapes introduced within his diaries. The Battle of Hamburg was one of the last battles of WWII fought on German soil, more notably where the remaining troops of the German Parachute Army fought the British corps for the control of the city between April $18^{\text {th }}$ and May $3^{\text {rd }} 1945$. In their account of the German resistance which the British faced at the end of April and the beginning of May 1945, historians often reference the fierceness of the conflicts, the presence of $88 \mathrm{~mm}$ guns spread around the city, how the $53^{\text {rd }}$ Division, supported by the $1^{\text {st }}$ Royal Tank Regiment, assaulted the woods and captured all remaining German troops (2,000 men) and how the Germans formally surrendered Hamburg on the May $3^{\text {rd }} 1945$. Some of these facts are illustrated in Ardizzone's diaries as he sketches and references the presence of British tanks, gunfire, $88 \mathrm{~mm}$ pointing down the road, air raid sirens, the battlefields, enemy shells, burning houses, etc.

$m$ the ink and wash executed on thicker watercolor paper with grid lines to the final larger ink and watercolor image produced for the WAAC, one can easily follow the evolution of the artist's choices of formats, supports and media. The colorful ink and wash accompanied with with grid lines enhances the relationship between the two sketched images, which clearly shows its genesis as it would eventually evolve into Ardizzone's famous larger scale ink and watercolor. The colorful ink and wash (Fig. 9: right-hand side of the diary entry) acts as a sort of synthesis of the two unpublished ink sketches (Fig. 9: left-hand side of the diary entry), combining the visual elements of both drawings as regards scale, perspective and details. His first quickly sketched 
image is that of a closely knit group of figures barely distinguishable as human bodies: it offers the same perspective lines as the colorful ink and wash disclosing how the representation of soldiers and civilians walking down a long narrow road lined with tall trees evolved. The second sketch provides a different perspective on what Ardizzone has witnessed as he focuses his attention on a few male figures (German soldiers). His portraits offer close-ups of faces and bodies carrying what Ardizzone describes in his diary entry as "odd shaped bundles." Their coats, hats, belongings and physical demeanor illustrate what he describes in his diary entry where he jots down the color of their clothing for the paintings he intends to make.

As is mentioned in my description of Figure 9, the two small ink sketches presented in the manuscripts of this particular diary entry were not published in Diary of a War Artist. Furthermore, the IWM makes no reference to them in their descriptions of the famous ink and wash which ensued. It is work in Ardizzone's archives that allowed for this most interesting discovery. Instead of reproducing these two preliminary sketches, Ardizzone and possibly his editor chose to publish a black and white image of the colorful ink and wash designed using grid lines. ${ }^{9}$ Paintings executed outside the pages of his diaries and embedded between the pages of his notebooks were never published in Diary of a War artist; this is a very interesting exception. There are many reasons why this ink and wash was included in the published edition of his diaries: it portrays the defeat of the Germans in April 1945 surrendering to the British and their allies, it is embedded within Ardizzone's fourth and last illustrated diary documenting his last trip to Germany, and this colorful sketch gave rise to one of Ardizzone's very popular war paintings: The Wehrmacht, May 1945.

The format and stylistic features of the two initial sketches, the grid lines used by Ardizzone to structure the colorful and more detailed rendition of this historical moment as he prepares for the final execution of his spectacular ink and watercolor (whose antecedents are the three sketches found in his fourth diary) result from experimentations. As we have seen throughout our article, the concept of "format" references various parameters including the scale, dimension, material and editorial characteristics of Ardizzone's artistic production. In order to commit to memory what he has witnessed and what he wants to include in the watercolor he plans on executing from his sketches, Ardizzone turns to language. The description of what he witnesses is briefly jotted down in his diary entry which is stripped of the details that Ardizzone was so accustomed to delivering: “To Lubeck [...]. The road an amazing sight -columns of our vehicles going forward, while German soldiers by the thousand come trudging the opposite way- without arms, without guards, carrying odd-shaped bundles. An army which has just given in" (Diary of a War Artist 208). However, his brief descriptions of the two initial sketches are enhanced at the end of the diary entry by quick notes destined to remind Ardizzone of the "color and dress of German prisoners" for the ink/ wash and eventual larger ink and watercolor he would execute for the WAAC: "Grey greatcoats and caps. Short green jackets. Gaiters - some with and without. Some in khaki and peak less caps, in fact almost an infinite variety" (208). The two sketches omitted from the published edition of his diaries (Fig. 9: left-hand side of the diary entry) are reminiscent of the same brevity adapted in his narrative: the first image offers a blurred, impressionistic image of what he witnessed and the second is a closeup portrait of German soldiers wearing traditional "greatcoats, caps and gaiters" and carrying an unidentifiable package. When we go beyond these two initial sketches, to the colorful ink and wash executed on another support (thicker watercolor paper) and 
structured with the help of grid lines, we quickly realize that Zerbib's less restrictive definition of format is extremely relevant for our study of Ardizzone's play with format. His various images, executed with different media, on different supports, and for different purposes commit to memory what he witnessed and the watercolor that they inspired. Ultimately, these phenomena (support, media, dimension, word/image relationships), all related to the concept of "format," serve to provide "cognitive frameworks" that guide Ardizzone's subjective experience and the manner in which his visual and verbal testimonials of WWII were communicated. Throughout my article, I have mentioned one phenomenon which has a prominent role in Ardizzone's play with format and is intricately related to questions of support, media, dimension and the transformative nature of his diaries. I would like to end my study of his diaries with a brief analysis of the dozens of unpublished sketches (pencil, ink and wash) embedded between the pages as they add another layer of complexity to our appreciation of Ardizzone's spectacular diaries.

\section{The embedded sketches and ink washes: editorial formatting challenges}

18 As was previously mentioned at the beginning of my article, the decision not to publish the majority of the images executed by Ardizzone outside of his diary and embedded between the pages of his notebooks is complex. This omission may be related to all sorts of problems (copyright, authorship, editorial and formatting issues), as well as to challenges stemming from inadequate word processing and computer technology. Unlike the images of landscapes, war paraphernalia or portraits of the military and civilians that Ardizzone encountered during his travels through North Africa and Europe, the sketches drawn and painted on these loose sheets of paper are not accompanied by words, textual descriptions or contextual references which serve to anchor the images within an historical, geographical, and cultural context. Details specifying the time, space or events depicted as well as Ardizzone's reactions to what he has witnessed are not provided, contrary to the sketches introduced within the pages of his bound notebooks where words dominate. Like so many of the images in his diaries, these drawn and rare ink/wash images are not the subject of figures of ekphrasis which play such an important role in the genesis of Ardizzone's artistic production. These images are arbitrarily embedded within the pages of the diaries and are only loosely related to Ardizzone's autobiographical accounts. Furthermore, they do not display the same illustrative function that his sketches exhibit as they are deprived of any textual references. ${ }^{10}$

As we can see in some of the excerpts I have quoted, certain sketches or ink and washes loosely embedded between the pages of his diaries appear to be executed as expanded versions of some of the smaller scaled sketches drawn directly onto the pages of his diaries. My consultation of these numerous unpublished images literally bulging out of the manuscripts of Ardizzone's diaries has allowed me to observe that the landscape format is the preferred structure for the execution of these particular sketches. War paraphernalia is the chosen subject matter and at times graphic paper or gridding lines are used to format the initial sketched images, which were often destined to become the object of larger scale watercolors for the WAAC. In many instances, Ardizzone's sketches and small-scale ink/water paintings are reminiscent of many artists' 
preparatory work, often executed on supports outside a bound sketchbook (da Vinci, Turner, Nash, Moore), deprived of any contextual details (time, place, events, and individuals referenced) and like these great artists, Ardizzone's sketches/ink and watercolors deserve to be acknowledged, published, and analysed. They play a crucial role in his artistic endeavours, are all thematically related to Ardizzone's travels during the war, to his verbal/pictorial testimonials presented in his diaries and to his body of larger ink and watercolors commissioned by the WAAC during the war. They act as a secondary visual narrative, which complements the form and content of his illustrated diaries, but their free-standing format allows Ardizzone the convenience of expanding his preliminary sketches, executing larger more detailed images, combining different media (ink and watercolor) and supports of various dimensions. They play an intermediary role as they are produced between two artistic projects: they appear to have been made after the sketches which serve to illustrate his diaries and precede the production of larger watercolors he was commissioned to paint. They have a genetic function: they allow us to perceive the evolution of Ardizzone's visual testimonials of war, to grasp the role that these extra images (drawn and painted) played in the execution of his stunning and world-renowned ink and watercolors exhibited all over Europe and North America. They give rise to a particular play with format as they introduce new media, supports of different dimensions and wonderful details and colors that distinguish them from the preliminary sketches which serve to illustrate his diaries. In this respect, they "combine the thematic preoccupations with memory [Ardizzone's], to his experiments with the material and tangible" (Tanderup Linkis 20) dimensions of artistic expression.

The most spectacular of these colorful images loosely embedded between the pages of his diaries actively partake of the intermedial aspect of Ardizzone's production as they exemplify a definitive "crossing of borders between media" (Rajewsky 46). From the drawn sketches (pencil and ink) to the ink washes, and finally to the watercolors commissioned by the WAAC, these images display various types of intermedial relations and specific ties to Ardizzone's conception of memory. There is the "literal sense of memory" (as in the relationship between the creation of his sketches/paintings and his "personal recollections" of war), and there is the "cultural sense of memory" his images embody: a memory focussed on the "cultural production, communication and circulation of memories" (Tanderup Linkis 21). For many historians, the cultural productions of memory are intrinsically linked to the collective processes of remembering and, as Tanderup Linkis so astutely observes, cultural memory reaches beyond personal recollections of the individual and takes place "between texts, media, people: they are setting the agenda for future acts of remembrance within societies and cultural groups" (22). Ardizzone's visual testimonies of war sketched, expanded upon as ink/watercolors and transformed into beautiful watercolors were the result of a highly creative and transformative process. They provide an intimate perspective on what he witnessed, chose to describe, draw, and paint. These images also bear witness to his deep desire to communicate his memories through images that have cultural and historical significance. The importance that his artistic production had in communicating "memories and constructing a shared understanding of the past" (Tanderup Linkis 21) could never have been imagined by Ardizzone or other artists tasked with the same challenges during WWI and WWII. The reading of his illustrated diaries and numerous paintings executed during the war allows us to fully experience what Tanderup Linkis describes as cultural memory, the "process of interaction 
between the past and the present at different levels, in culture, between people, texts and media" (19). The aesthetic beauty of Ardizzone's artistic production related to his testimonies of war, the unexplored documents preserved with his archives in Britain, and the intricacy of his play with format, will undoubtedly continue to attract the attention of scholars from various fields of inquiry for decades to come.

\section{BIBLIOGRAPHY}

\section{Works cited}

ARDIZZONE, Edward. Baggage to the Enemy. London: John Murray, 1941.

ARDIZZONE, Edward. Battle in an Orchard of Almond Trees in Sicily: Morning of July $21^{\text {st }} 1943$.

Watercolor. 1943. London, Imperial War Museums.

ARDIZZONE, Edward. “The Born Illustrator.” Motif 1 (November 1958): 37-54.

ARDIZZONE, Edward. Diary of a War Artist. London: The Bodley Head, 1974.

ARDIZZONE, Edward. The Wehrmacht, May 1945. Watercolor and ink. 1945. London, Imperial War Museums.

ARDIZZONE, Edward. Wehrmacht on the Road to Lübeck. Watercolor. 1945. London, Imperial War Museums.

de BIASI, Pierre-Marc. "La notion de 'carnet de travail' : le cas Flaubert." Carnets d'écrivains 1. Paris : Éditions CNRS, 1990. 23-56.

BUNKERS, Suzanne L. and Cynthia A. HUFF. “Issues in Studying Women's Diaries: A Theoretical and Critical Introduction." Inscribing the Daily Critical Essay on Women's Diaries. Ed. S. Bunker and C. Huff. Amherst: University of Massachusetts Press, 1996. 1-22.

COLLOT, Michel. "Les Carnets d'André du Bouchet : une écriture en marche." Carnets d'écrivains 1. Paris: Éditions CNRS, 1990. 177-202.

FOSS, Brian. War Paint: Art, War, State and Identity in Britain, 1939-1945. New Haven and London: Yale University Press, 2007.

FREEMAN, C. Denis, and Douglas COOPER. The Road to Bordeaux. New York and London: Harper, 1941.

LEBLANC, Julie. "Landscapes of War in Edward Ardizzone's Illustrated Diary and Artistic Productions: The Political and Pictorial Landscapes of the Second World War." Illustrating History / Illustrer l'histoire. Ed. Sophie Aymes, Nathalie Collé, Brigitte Friant-Kessler and Maxime Leroy. Nancy: PUN; Éditions Universitaires de Lorraine, 2019. 203-224.

MAUROIS, André. The Battle of France. London: Right Book Club, 1940.

MIZE, Dianne. “The Importance of a Painting's Format: Visual Composing.” Blogspot. Com/ 2011/12/importance-of-painting-format.html (page accessed May $3^{\text {rd }}, 2021$ ). 
NEWTON, Eric. War Through Artists Eyes. London: John Murray, 1945.

POWERS, Alan. Edward Ardizzone: Artist and Illustrator. London: Lund Humphries, 2016.

RAJEWSKY, Irina. "Intermediality, Intertextuality and Remediation: A Literary Perspective on Intermediality." Intermediality, History and Theory of the Arts, Literature and Technologies 6 (Fall 2005): 43-64.

TANDERUP LINKIS, Sara. Memory, Intermediality, and Literature. New York: Routledge, 2029.

TANSELLE, Thomas. “The Concept of Format.” Studies in Bibliography 53 (2000): 67-115.

TOLSON, Roger. Art from the Second World War. London: Imperial War Museum, 2007.

WHITE, Gabriel. Edward Ardizzone: Artist and Illustrator. New York: Schoken Books, 1979.

ZERBIB, David. “Introduction.” In Octavo. Des formats de l'art. Annecy: ESAAA Éditions; [Dijon]:

Presses du Réel, 2015. 13-20.

\section{NOTES}

1. Ardizzone published numerous illustrated children's books. During WWII he illustrated and published three books: Baggage to the Enemy (a book he dictated to his sister and illustrated with pen and ink drawings). He also beautifully illustrated André Maurois's The Battle of France and C. Denis Freeman and Douglas Cooper's monograph The Road to Bordeaux.

2. The WAAC (War Advisory Art Committee) was created in 1939 within the Ministry of Information with the goal of compiling, through commissions and purchased artworks, a documentary and artistic history of the kingdom during WWII. As Brian Foss explains, "the WAAC acquired works from more than 400 artists. The committee focused upon complementary criteria: aesthetic quality, catholicity of taste, and support for those whose work was seen to evince a visual culture that spoke to specifically British constituencies and, by extension, promoted an inclusive, national sensibility" (3). In his introduction to Art from the Second World War, Roger Tolson explains that "the development of official artist schemes during the First World War enabled an art that was not idolising or unquestioningly supportive of government and leaders. The honesty and integrity of eye-witness artists allied to deliberately liberal patronage resulted in a set of images that grappled with the painfully complex consequences and morality of war" (5). One must also mention Gabriel White's wonderful monograph on Ardizzone: Edward Ardizzone: Artist and Illustrator.

3. I am extremely grateful to the members of the Ardizzone family for their kindness in allowing me to reproduce photographs I took of the illustrated manuscripts of Diary of $a$ War Artist archived at the IWM in London. I am also very thankful for their permission to reproduce photographs of three of Ardizzone's paintings also held in trust at the IWM.

4. My translation of Zerbib's eloquent description of the concept: "La notion de format renvoie en effet à un plan mal identifié, parce que trop relégué [...], trop exposé dans l'évidence d'une variable technique [...]. Il semble pourtant légitime de le considérer comme un opérateur clé des pratiques matérielles et symboliques. Nous proposons de l'entendre ici comme une construction médiatrice qui commande des modes 
d'inscription, de codage, de traduction, d'implémentation, d'exposition, de filtrage et d'usage de formes et d'information" (Zerbib 16).

5. Second World War museums by and large followed the example of Great War museums. There was an unstated rule of decorum in representation, ruling out ugly or shocking images: when bodies were represented, they were rarely dismembered. Ardizzone sketches one blurred image of a human casualty in his diary. It is in fact after consulting the famous ink and wash, which was executed from the initial sketch, that I recognized the dismembered body of a soldier as the colorful image offers a more detailed portrayal of this horrific scene. I am referencing the sketch introduced in Diary of a War Artist (20) and the painting Battle in an Orchard of Almond Trees in Sicily: Morning of July $21^{\text {st }} 1943$.

6. My translation of the original text: "la frontière entre carnets de voyage et carnets de travail peut quelquefois manquer de netteté, lorsque ledit voyage est par exemple l'occasion [...] d'une enquête documentaire" (de Biasi 30).

7. The IWM website presents this "object description": "Image: British Armoured vehicles moving in orchard country on a misty morning. In the middle ground to the left are two tanks, with a Bren Gun Carrier slightly before and to the right of them, all ready to move off. In the centre foreground an officer is walking away about to pass the Bren Gun Carrier. In the left foreground a group of figures look on and wait. The ARK moves into position to bridge what could be a stream or canal. In the background there is a group of farm buildings". URL: https://www.iwm.org.uk/collections/item/object/ 713 (page accessed May $3^{\text {rd }}$, 2021).

8. The IWM describes The Wehrmacht, May 1945 in this manner: "Object description. Image: a view down a tree lined road in Germany, with a column of defeated and injured German soldiers walking towards the viewer. Some of the men drag wheeled carts of belongings with them and there is an air of dejection about the scene. Two German soldiers rest in the ditch to the right of the road" (Imperial War Museums). URL: https://www.iwm.org.uk/collections/item/object/713 (page accessed May $3^{\text {rd }}$, 2021).

9. It is important to mention that the website of the IWM does not reference these two initial sketches which were omitted from the published edition of his diaries in Diary of $a$ War Artist. As the excerpts I presented indicate, these were substituted by the colorful ink and wash executed outside of the diary. The IWM also oddly relates the particular diary entry (May 03, 1945) to another ink and wash image (Wehrmacht on the Road to Lübeck), which portrays the same historical moment from a very different perspective (from the back of the row of lined up German soldiers). The landscape and portraits are formatted differently, focusing on the bodies of tired soldiers sitting in a ditch along the heavily treed road.

10. I would like to mention my previous publication on Ardizzone's archives focussed on the illustrative function of his diaries: "Landscapes of War in Edward Ardizzone's Illustrated Diary and Artistic Productions: The Political and Pictorial Landscapes of the Second World War" (LeBlanc). 


\section{ABSTRACTS}

The object of my article is Edward Ardizzone's manuscripts of his four illustrated war diaries (1943-1945) preserved in his archives at the IWM in London, the published edition of his diaries entitled Diary of a War Artist (1974), the larger ink/watercolors commissioned by the WAAC during WWII which ensued from his preliminary sketches introduced in the bound pages of his diaries and finally the numerous unpublished images embedded between the manuscript pages of his diaries. His diaries represent a rich literary and pictorial context to study the aesthetic and transformative elements of format. Ardizzone's play with format is multidimensional and complex as he uses various media (pencil, pen, watercolor, ink and wash) and different supports (pages of his bound diaries, sheets of paper, graph paper, watercolor paper) which vary greatly in dimension. The ever-changing format of his handwritten diary entries punctuated with sketches which visually interrupt his narrative, enhances the complexity of the diaries' formats. Finally, the discrepancies I have observed between the manuscript versions of his diaries and its published edition adds another layer of complexity to my study of how format influenced Ardizzone's creative output but also imposed physical restrictions on his artistic endeavours.

Cet article porte sur les manuscrits d'Edward Ardizzone : ses quatre journaux de guerre illustrés (1943-1945) conservés dans ses archives à l'Imperial War Museum de Londres, l'édition publiée de ses journaux intitulée Diary of a War Artist (1974), les aquarelles commandées par la WAAC pendant la Seconde Guerre mondiale, qui découlent de ses esquisses préliminaires introduites dans les pages reliées de ses journaux, et enfin les nombreuses images inédites insérées entre les pages manuscrites de ses journaux. Ses journaux représentent un riche contexte littéraire et pictural pour étudier les éléments esthétiques et transformateurs du format. Le jeu d'Ardizzone avec le format est multidimensionnel et complexe, car il utilise divers médias (crayon, plume, aquarelle, encre et lavis) et différents supports (pages de ses agendas reliés, feuilles de papier, papier millimétré, papier aquarelle) dont les dimensions varient énormément. Le format est en constante évolution dans les feuillets manuscrits de son journal ponctué de croquis. Ces dessins de guerre, qui interrompent visuellement son récit, renforcent la complexité des formats mis en jeu dans ses journaux. Enfin, les écarts qui existent entre les versions manuscrites de ses journaux et son édition publiée ajoutent une autre couche de complexité à mon étude de la manière dont le format a influencé les créations d'Ardizzone et a imposé des restrictions à sa production artistique.

\section{INDEX}

Mots-clés: Ardizzone (Edward), journaux personnels, dessins, peintures, manuscrits inédits, seconde guerre mondiale, rapports texte/image, format

Keywords: Ardizzone (Edward), diaries, sketches, paintings, unpublished manuscripts, second world war, word/image relationships, format

\section{AUTHOR}

\section{JULIE LEBLANC}

University of Toronto

Julie LeBlanc is a Full-Professor in the Department of French and the Centre for Comparative 
Literature at the University of Toronto. Her research pertains to autobiographical narratives, word and image theories and genetic criticism. She has had numerous research grants from SSHRC, a university federal granting agency on various topics dealing with her principal fields of inquiry. She is an active member of l'Institut des Textes et Manuscrits Modernes (ENS, Paris : équipe de recherche Autobiographie et Correspondence). Her more recent funded research project (2015-20) deals with unpublished illustrated diaries and notebooks of writers and artists of WWI and WWII. She is the author of numerous articles and book chapters. She has published theoretical and critical books : Genèses de soi : l'écriture du sujet féminin dans quelques journaux d'écrivaines ; Énonciation et inscription du sujet : textes et avant-textes de Gilbert La Rocque ; Les Masques de Gilbert La Rocque ; Narrativité et iconicité au féminin (under review). Her new monograph (Journaux de guerre illustrés, nearing completion) pertains to the intermedial and autobiographical nature of the war diaries / notebooks of writers and artists. She has also edited several thematic volumes of Texte. Revue de théorie et de critiques littéraire, Recherches sémiotiques, Voix et images, Arborescence, etc. pertaining to autobiography, genetic criticism, feminist writings, intermediality, rhetoric and literary theory. 